Volume 2 Nomor 1, Mei 2021: h. 24 - 42

P-ISSN: 2722-4465, E-ISSN: 2746-8151

Lisensi Creative Commons Atribusi-NonCommercial 4.0 Internasional

\title{
Perlindungan Hukum Bagi Artis atas Penggunaan Potret dalam Cover Novel Fanfiksi
}

\author{
Paramita Cahyaning Dewanti ${ }^{1}$, Rahmadi Indra Tektona ${ }^{2}$ \\ 1, 2, Fakultas Hukum Universitas Jember, Jember, Indonesia. \\ 2 E-mail: rahmadiindra@unej.ac.id
}

\begin{tabular}{|c|c|}
\hline Dikirim: 22/01/2021 & Dipublikasi: 31/05/2021 \\
\hline Info Artikel & Abstract \\
\hline \multirow[t]{2}{*}{$\begin{array}{l}\text { Keywords: } \\
\text { Legal protection; Copyright; } \\
\text { Fanfiction Novel Cover. }\end{array}$} & $\begin{array}{l}\text { Intellectual Property Rights translated from Intellectual Property } \\
\text { Right are the right to do something on the intellectual property which } \\
\text { is regulated by applicable norms or laws. The purpose of this thesis } \\
\text { research consists of general objectives and specific objectives, namely } \\
\text { to find out and analyze the form of legal protection for Portraits, legal } \\
\text { consequences, and efforts to resolve Portrait disputes. The research } \\
\text { method includes the juridical - normative research type, while the } \\
\text { research approach used is the statute approach. The result of this } \\
\text { research is that portrait work is one of the copyrighted works protected } \\
\text { by copyright law. which is contained in article } 40 \text { paragraph 1. This } \\
\text { protection is given to the creator, namely the photographer and the } \\
\text { copyright holder is the person photographed. This protection is given } \\
\text { to motivate and encourage the creativity of creators who can create } \\
\text { economic growth based on the scope of art, literature and science and } \\
\text { provide an understanding to the public that portrait works are } \\
\text { protected by law No. } 28 \text { of } 2014 \text { concerning copyright, where there is } \\
\text { a prohibition for other people. use the copyright work arbitrarily } \\
\text { without the permission of the creator or copyright holder. Acts of } \\
\text { violating the copyright of Portrait's works that are used commercially } \\
\text { without rights can be sued civil or criminal or can be done both, but if } \\
\text { you want to do both, you must prioritize civil settlement then } \\
\text { criminally. but the verdict of his civil case cannot waive his criminal } \\
\text { sentence. Then to resolve the dispute, it can be done by litigation and } \\
\text { also in non-litigation, namely dispute resolution by negotiation, } \\
\text { mediation, and arbitration. }\end{array}$ \\
\hline & Abstrak \\
\hline $\begin{array}{l}\text { Kata Kunci: } \\
\text { Perlindungan Hukum; Hak } \\
\text { Cipta; Cover Novel } \\
\text { Fanfiksi. }\end{array}$ & $\begin{array}{l}\text { Hak Kekayaan Intelektual terjemahan dari Intellectual Property } \\
\text { Right adalah hak untuk berbuat sesuatu atas kekayaan } \\
\text { intelektual tersebut yang diatur oleh norma-norma atau hukum } \\
\text { yang berlaku. Tujuan penelitian yaitu untuk mengetahui dan } \\
\text { menganalisis bentuk perlindungan hukum terhadap Potret, } \\
\text { akibat hukum, dan upaya penyelesaian sengketa Potret. } \\
\text { Metode penelitian meliputi tipe penelitian yuridis - normatif, } \\
\text { sedangkan pendekatan penelitian yang digunakan adalah } \\
\text { pendekatan perundang - undangan (statute approach) dan } \\
\text { Pendekatan Konseptual (Conceptual Approach).. Hasil dari } \\
\text { penelitian ini adalah Karya potret merupakan salah satu karya }\end{array}$ \\
\hline
\end{tabular}


DOI:

10.47268/ballrev.v2i1.467 cipta yang dilindungi oleh undang-undang hak cipta yang termuat dalam Pasal 40 ayat 1 . Perlindungan tersebut diberikan kepada pencipta yaitu fotografer dan pemegang hak cipta ialah orang yang difoto. Perlindungan tersebut diberikan guna memotivasi dan mendorong kreatifitas pencipta yang dapat menciptakan pertumbuhan ekonomi berbasis pada ruang lingkup seni, sastra dan ilmu pengetahuan dan memberi pemahamaan kepada masyarakan bahwa karya potret dilindungi oleh Undang-Undang Nomor 28 tahun 2014 tentang Hak Cipta, dimana adanya larangan untuk orang lain menggunakan karya cipta tersebut semena - mena tanpa seizin pencipta maupun pemegang hak ciptanya. Perbuatan melanggar hak cipta karya Potret yang digunakan secara komersial tanpa hak dapat digugat secara perdata maupun dituntut secara pidana atau dapat dilakukan kedua-duanya, namun jika ingin melakukan keduanya harus mendahulukan penyelesaian secara perdata kemudian secara pidana. Tetapi putusan perkara perdata nya tidak dapat menghapuskan hukuman pidananya. Kemudian untuk menyelesaikan sengketa tersebut dapat dilakukan secara litigasi dan juga secara non litigasi yaitu penyelesaian sengketa dengan negoisasi, mediasi, dan arbitrase.

\section{Pendahuluan}

Hak Kekayaan Intelektual (HKI) terjemahan dari Intellectual Property Right adalah hak untuk berbuat sesuatu atas kekayaan intelektual tersebut yang diatur oleh norma-norma atau hukum yang berlaku (Sutedi, 2009: 38). HKI berhubungan dengan benda tidak berwujud serta melindungi karya intelektual yang lahir dari cipta, rasa, dan karsa manusia (Utomo, 2010: 2). Sifat dari HKI adalah hak kebendaan, yaitu hak atas sesuatu benda yang bersumber dari hasil kerja otak atau hasil kerja rasio, dimana hasil kerja tersebut dirumuskan sebagai intelektualitas, sehingga ketika sesuatu tercipta berdasarkan hasil kerja otak maka dirumuskan sebagai HKI (Labetubun, 2018: 138). Menurut Rachmadi Usman HKI adalah hak atas kepemilikan terhadap karya-karya yang timbul atau lahir karena adanya kemampuan intelektualitas manusia dalam bidang ilmu pengetahuan dan teknologi. Karya-karya tersebut merupakan kebendaan tidak berwujud yang merupakan hasil kemampuan intelektualitas seseorang atau manusia dalam bidang ilmu pengetahuan dan teknologi melalui daya cipta, rasa, karsa dan karyanya (Usman, 2006: 2), sehingga titik tolak nilai yang dilindungi oleh hak kekayaan intlektual adalah proses berpikir penciptanya, maka hak tersebut berupa hak untuk mempertahankan karangan miliknya dan hak untuk memanfaatkan atau menggunakan karangan tersebut, misalnya untuk mendapatkan penghargaan secara ekonomis (Muchtar A H Labetubun \& Fataruba, 2016: 4-5).

Menciptakan suatu karya bukanlah pekerjaan yang mudah dilakukan karena membutuhkan kemampuan pemikiran intelektual dan kreativitas seseorang. Pelanggaran terhadap hak ekonominya akan menyebabkan kreatifitas mereka berkurang atau lahirnya karya yang tidak bermutu sama sekali (Rahayu, 2000). Perlindungan hak cipta bersifat otomatis dan timbul setelah suatu ciptaan diwujudkan dalam bentuk yang nyata (tangible form). Pendaftaran atau pencatatan hak cipta bersifat sukarela/tidak wajib kerena pendaftaran atau pencatatan tidak menimbulkan hak cipta (Muchtar A H Labetubun, 2019: 152). Oleh karenanya, setiap ciptaan baik itu karya tulis maupun karya artistic secara 
otomatis dilindungi oleh Hak Cipta. Hak Cipta merupakan salah satu bagian dari HKI yang bergerak di bidang seni, sastra, dan ilmu pengetahuan dimunculkan untuk memotivasi dan mendorong kreatifitas pencipta yang dapat menciptakan pertumbuhan ekonomi berbasis pada ruang lingkup seni, sastra dan ilmu pengetahuan (Lutviansori, 2010: 39). Hak Cipta adalah hak eksklusif yang hanya diperuntukkan bagi pencipta atau penerima hak untuk mengumumkan atau memperbanyak ciptaanya atau memberi izin untuk itu dalam bidang pengetahuan, kesenian, dengan pembatasan-pembatasan tertentu (Fuady, 2011: 208), pada dasarnya hak cipta adalah hak untuk menyalin, mengadaptasi atau memproduksi suatu karya, hak cipta dimungkinkan oleh pemegang hak untuk membatasi penggandaan atau dalam bentuk apapun tanpa izin yang tidak sah dari suatu ciptaan (Labetubun, 2021: 49), yang diatur dalam Undang-Undang Nomor 28 tahun 2014 tentang Hak Cipta. Sebelumnya Undang-Undang ini dilakukan beberapa kali pembaharuan dimulai dari lahirnya UndangUndang Nomor 7 tahun 1987 yang kemudian harus diperbarui kembali sebagai bentuk konsekuensi yuridis keikutsertaan Indonesia dalam perjanjian multirateral GATTMTO dan melahirkan Undang-Undang Nomor 12 tahun 1997 tentang Hak Cipta, hingga dilakukan pembaruan yang terakhir yaitu undang-undang nomor 28 tahun 2014 yang masih berlaku hingga saat ini.

Pada era Digital ini perkembangan teknologi yang semakin pesat dengan dukungan jaringan internet memudahkan kita untuk mendapatkan dan menyebarkan sumber informasi semakin cepat dan luas, dengan demikian dapat diketahui keberadaan ilmu pengetahuan dan teknologi saling berdampingan satu dengan yang lainnya. Oleh karena itu dengan seiring berjalannya waktu karya-karya tersebut berkembang secara pesat, tidak lagi hanya sekedar di kehidupan sosial tetapi juga beredar di kehidupan maya Fanfiksi (Fanfiction) contohnya. Fanfiksi sendiri merupakan hasil karya yang di buat oleh penggemar berdasarkan kisah, karakter, dan latar yang sudah ada. Fanfiksi bisa berlaku untuk film, komik, novel, artis, dan karakter terkenal lainnya. Rebbeca W. Black menyatakan "Fanfictions are fan-produced texts that derive from forms of media, literature, and popular culture" (Black, 2007), yang dapat diartikan Penggemar menulis fanfiksi karena adanya kemungkinan ketidak sesuaian dengan keinginan atau harapan mereka terhadap karya asli, oleh karena itu mereka mengadaptasi karya asli tersebut dan mengolahnya dengan menulisnya kembali dalam bentuk fiksi. Plot dari fanfiksi ini merupakan imajinasi dari Penggemar terhadap idolanya dan melihat mayoritas cover dari fanfiksi tersebut menggunakan potret dari artis yang digunakan sebagai karakter, dan mengeditnya sesuai judul maupun tema yang di harapkan penggemar tersebut.

Penggunaan potret artis yang diedit untuk cover fanfiksi dan dikomersilkan tersebut tanpa persetujuan artis dalam potret tersebut. Dimana diketahui bahwa hasil Karya cipta seseorang bersifat hak eksklusif bagi penciptanya untuk merubah, memperbanyak, memperjual belikan maupun menggunakan tanpa larangan apabila telah memiliki izin dari pencipta.

\section{Metode Penelitian}

Penggunaan metode yang tepat, analisis terhadap objek yang dikaji juga dapat dilakukan dengan benar serta dapat dipertanggungjawabkan secara ilmiah. Metode penelitian merupakan cara kerja untuk memperoleh data dengan hasil konkrit. Metode penelitian tidaklah sama antara satu ilmu dengan ilmu yang lain, terdapat banyak metode yang digunakan sesuai dengan identitas keilmuannya masing-masing. Seperti halnya penelitian hukum yang menjadi identitas khusus untuk mendapatkan data-data berupa aturan hukum, prinsip-prinsip hukum, maupun doktrin-doktrin hukum yang ada terhadap 
isu hukum yang dihadapi (Marzuki, 2016: 35). Metode penelitian merupakan pedoman untuk menganalisa sutu permasalahan atau isu hukum agar dapat menghasilkan kesimpulan yang mendekati kebenaran sesungguhnya. Terkait hal tersebut, dalam penelitian skripsi digunakan tipe penelitian Yuridis Normatif (Legal Research) dapat dilakukan dengan mengkaji hukum formal seperti Undang-Undang, literatur-literatur bersifat teoritis dan kemudian dihubungkan dengan permasalahan yang dibahas, (Marzuki, 2016: 29) menggunakan pendekatan pendekatan Undang-Undang ( statute approach) dan pendekatan konseptual (conseptual approach).

\section{Hasil dan Pembahasan}

\subsection{Perlindungan Hukum Terhadap Potret Artis Yang Digunakan Sebagai Cover Novel Fanfiksi Secara Komersial Tanpa Hak Berdasarkan Undang-Undang Nomor 28 Tahun 2014 Tentang Hak Cipta}

\subsubsection{Potret Artis Sebagai Cover Novel Fanfiksi}

Eksistensi Novel Fanfiksi telah menjadi budaya populer diseluruh dunia, sehingga mulai menjadi diskusi hukum karena keberadaannya. Ditambah dengan pengalihan wujudan fanfiksi menjadi Novel Fanfiksi yang dikomersialkan dan diperjual belikan diseluruh toko buku di Indonesia sehingga memperlihatkan sisi abu abu dari hukum hak cipta. Fanfiksi merupakan suatu karya fiksi yang dibuat oleh seorang penggemar dengan memakai latar belakang, tokoh, kisah karakter atau dari suatu film, komik, novel, artis terkenal dan karakter terkenal lainnya yang sudah ada. Menurut Profesor Rebecca Tushnet fanfiksi digambarkan sebagai (Lipton, 2014): "Segala kreativitas tertulis yang didasarkan pada segmen budaya populer, seperti acara televisi, film, novel, artis terkenal dan tidak diproduksi sebagai tulisan 'profesional.

Di era sebelum adanya internet, fanfiksi biasanya difotokopi dengan tangan dan diedarkan melalui "fanzines" (majalah buatan penggemar) yang bersifat non-komersial dan saat adanya perkumpulan penggemar (gathering fan). Munculnya Internet menyebabkan ledakan fandoms online yang biasanya mendistribusikan karya-karya mereka secara gratis. Sehingga masi banyak masyarakat yang cinderung melanggar hak cipta. Karena kemajuan teknologi membuat perkembangan hukum semakin rumit sehingga menciptakan sisi abuabu dari eksistensi Novel Fanfiksi dalam hukum hak cipta. Novel Fanfiksi sendiri merupakan satu hasil dari karya cipta dibidang sastra yang tercipta atas imajinasi author yang terinspirasi oleh tokoh fiksi terkenal yang telah ada ataupun artis terkenal sebagai tokoh dalam cerita yang dibuatnya.

Perlindungan hak cipta di Indonesia telah dilaksanakan melalui rumusan undangundang yang mengatur tentang hak cipta secara rinci, namun pada kenyataannya penerapan undang-undang tersebut belum sepenuhnya dilaksanakan. Perlindungan hukum sebagai gambaran dari fungsi hukum yaitu suatu konsep dimana hokum dapat memberikan keadilan, ketertiban, kepastian, kemanfaatan dan ketentraman. Perlindungan hukum selalu dikaitkan dengan konsep rechtstaat atau konsep Rule of law, karena lahirnya konsep-konsep tersebut tidak lepas dari keinginan untuk mengakui dan melindungi hak asasi manusia. Menurut Van Apeldoorn tujuan hukum ialah mengatur tata tertib masayarakat secara damai dan adil. Perdamaian di antara manusia dipertahankan oleh hukum dengan melindungi kepentingan-kepentingan manusia yang tertentu, kehormatan, kemerdekaan, jiwa, harta dan sebagainya terhadap yang merugikannya (Arrasjid, 2008: 39).

Faktanya, novel fanfiksi yang beredar di Indonesia paling sering menggunakan nama maupun potret artis terkenal yang bukan dari Indonesia. Misalnya, sebagian besar novel 
fanfiksi yang ada menggunakan potret artis dari negara Inggris dan Korea Selatan. Penggunaan potret artis terkenal sebagai cover dalam novel fanfiksi yang dikomersialkan tanpa adanya izin dari pemilik hak terkait termasuk kedalam penggunaan yang wajar atau pelanggaran hak cipta dapat dilihat dari pembatasan dan pengecualian terhadap karya cipta yang diwujudkan dalam pasal 41-43 Undang-Undang Hak Cipta, dalam Pasal 43 huruf (d) Undang-Undang Hak Cipta menyebutkan bahwa salah satu perbuatan tidak akan dianggap sebagai pelanggaran hak cipta meliputi: "Pembuatan dan penyebarluasan konten Hak Cipta melalui media teknologi informasi dan komunikasi yang bersifat tidak komersial dan/atau menguntungkan Pencipta atau pihak terkait, atau Pencipta tersebut menyatakan tidak keberatan atas pembuatan dan penyebarluasan tersebut.

Pasal 43 mengatur tentang perbuatan yang tidak dianggap sebagai pelanggaran hak cipta. Ketika suatu perbuatan dalam konten hak cipta telah bertentangan dengan pasal tersebut, maka perbuatan tersebut dianggap sebagai pelanggaran hak cipta. Sesuai dengan pasal tersebut maka, perbuatan penggunaan potret artis terkenal sebagai cover dalam Novel Fanfiksi merupakan perbuatan yang dianggap sebagai pelanggaran hak cipta. Pasal 1 angka 3 dalam undang - undang hak cipta telah disebutkan, bahwa "Ciptaan merupakan setiap hasil karya cipta di bidang ilmu pengetahuan, seni, dan sastra yang dihasilkan atas inspirasi, kemampuan, pikiran, imajinasi, kecekatan, keterampilan, atau keahlian yang telah diekspresikan dalam bentuk nyata". Novel Fanfiksi dikategorikan sebagai hasil karya cipta di bidang sastra dalam hal karya tulis lain selain yang disebutkan dalam pasal 40 dan juga sebagai karya lain dari hasil transformasi, maka dalam kedua pasal tersebut dapat disimpulkan bahwa Novel Fanfiksi merupakan salah satu dari ciptaan yang diakui dalam Hukum Hak Cipta di Indonesia.

\subsubsection{Perlindungan Hukum Bagi Subjek Dalam Potret Yang Digunakan Sebagai Cover Novel}

Penggunaan potret Artis terkenal sebagai cover dalam novel fanfiksi yang dikomersialkan berhak untuk mendapatkan royalti dari hasil penjualan ciptaan itu sendiri. Seperti yang disebutkan dalam pasal 1 angka 24 menyebutkan bahwa: "Penggunaan Secara Komersial adalah pemanfaatan Ciptaan dan/atau produk Hak Terkait dengan tujuan untuk memperoleh keuntungan ekonomi dari berbagai sumber atau berbayar."

Pasal 1 angka 21 memberikan pengertian royalti sebagai imbalan atas pemanfaatan Hak Ekonomi suatu Ciptaan maupun Produk Hak Terkait yang diterima oleh pencipta atau pemilik hak terkait. Sehingga pengguna yang menggunakan suatu ciptaan maupun produk Hak Terkait secara komersial harus membayar royalti sebagai imbalan pemanfaatan hak ekonomi kepada pencipta atau pemilik Hak Terkait. Hak cipta memberikan sejumlah hak eksklusif kepada seseorang maupun sekelompok orang yang menjadi objek atas potret, diantaranya:

1) Untuk mendapatkan royalti dari penggunaan potret dirinya dalam setiap kegiatan komersial yang mendatangkan keuntungan ekonomi

2) Melakukan pengumuman termasuk perubahan atas gambar dirinya sendiri

3) Melarang orang lain menggunakan potretnya tanpa seizinnya

4) Untuk mencantumkan namanya sebagai objek di dalam potret, dan

5) Untuk menolak setiap penggunaan yang dapat dianggap akan merugikan citra atas karya

Sebagaimana telah di jelaskan sebelumya, Pada pasal 40 ayat 1 huruf K bahwa yang dimaksud dengan "karya fotografi" meliputi semua foto yang dihasilkan dengan 
menggunakan kamera, sementara dalam Pasal 1 angka 10 Undang-Undang Nomor 28 tahun 2014 tentang Hak Cipta menyebutkan bahwa potret merupakan karya fotografi dengan objek manusia, Hak cipta atas potret timbul setelah potret tersebut berhasil diwujudkan dalam bentuk nyata baik masih dalam bentuk digital ataupun dalam bentuk cetak. Berdasarkan ketentuan dalam Undang-Undang Nomor 28 tahun 2014 tentang Hak Cipta yang dimaksud Potret yakni foto dengan objek manusia masuk ke dalam golongan karya fotografi, dalam hal ini dapat di ketahui bahwa fotografi adalah karya seni, Adapun karya seni menurut Keontjaraningrat ialah Seni adalah suatu kompleks dari ide-ide, gagasan, nilai-nilai, normanorma, dan peraturan dimana kompleks aktivitas dan tindakan berpola dari manusia dalam masyarakat dan biasanya berwujud benda-benda hasil manusia.

Namum definisi umum suatu seni adalah sesuatu yang diciptakan manusia tentang cara hidup berkembang secara bersama pada suatu kelompok yang memiliki unsur keindahan (estetika) secara turun temurun dari generasi ke generasi Menurut media yang digunakan, seni dibagi menjadi 3 (tiga) yaitu (Seputaran Pengetahuan, 2020):

1) Seni yang dapat dinikmati melalui media pendengaran atau (Audio art), misalnya seni musik, seni suara, dan seni sastra seperti puisi dan pantun.

2) Seni yang dinikmati dengan media penglihatan (Visual art) misalnya Lukisan, Poster, Seni Bangunan, Seni Gerak Beladiri dan sebagainya.

3) Seni yang dinikmati melalui media penglihatan dan pendengaran (Audio visual art) misalnya pertunjukan musik, pagelaran wayang, film.

Dari penjelasan di atas maka karya potret termasuk pada seni dengan media penglihatan (Visual Art) yang dapat di nikmati dengan cara dilihat, sehingga dapat disimpulkan karya potret termasuk karya fotografi dibidang seni yang merupakan suatu ciptaan yang dilindungi dan termuat dalam Undang-undang No.28 tahun 2014 Tentang Hak Cipta. Hak eksklusif dalam hak cipta ialah hak istimewa yang hanya dapat diperuntukkan bagi pemegangnya sehingga tidak ada pihak lain yang boleh memanfaatkan hak tersebut tanpa izin pemegangnya (Hariyani et al., 2018: 50). Kepemilik hak cipta potret apabila objeknya manusia berdasarkan Undang-undang Nomor 28 tahun 2014 Tentang Hak Cipta adalah orang yang dipotret (Model), yang mana wajahnya terlihat dalam hasil karya potret tersebut. Sementara pemegang hak cipta potret adalah orang yang berhak menguasai sebagian dari hak cipta potret. Hal tersebut dapat terjadi berdasarka dua situasi, antara lain (Darmawan, 2018: 67):

a) Potret dibuat oleh diri pribadi model dan hanya diperuntukan atas kepentingan pribadi sehingga baik hak moral ataupun hak ekonominya tidak mengalami pengalihan.

b) Potret yang dilakukan atas dasar permintaan, baik permintaan pribadi (model), permintaan fotografer ataupun permintaan instansi atau agensi.

1) Pertama, potret dibuat atas permintaan pribadi (model) maka pemegang hak ciptanya adalah pribadi (model).

2) Kedua, potret dibuat atas permintaan fotografer maka pemegang hak ciptanya adalah fotografer.

3) Ketiga potret dibuat atas dasar permintaan instansi/agensi, maka status pemegang hak cipta potret tersebut menjadi milik instansi. Dalam situasi kedua dan ketiga status pemegang hak cipta dimiliki berdasarkan kepada asas kepatutan dan kesepakatan bersama atau perjanjian. Hal ini dibenarkan oleh Pasal 16 ayat (2) Undang-Undang Hak Cipta yaitu 
pemegang hak cipta dapat beralih berdasarkan perjanjian atau sebab lain yang dibenarkan oleh Undang-Undang.

Menjadi sebuah kontroversi terkait perlindungan bagi subjek dalam potret, mengingat keindahan yang dihasilkan dalam potret tersebut tidak akan terwujud tanpa adanya subjek dalam potret. Potret merupakan ciptaan yang dilindungi oleh hak cipta dan memiliki hak ekslusif terdiri dari Hak moral (moral rights) dan Hak ekonomi (economic rights). Hak moral (moral rights) berlaku abadi atau tanpa batas waktu, artinya walaupun jangka waktu perlindungannya sudah habis, hak pencipta tetap dicantumkan namanya meski ciptaan tersebut telah dialihkan ke pihak lain dan berlaku selama pencipta hidup maupun setelah meninggal dunia. Karena adanya Hak Moral tersebut, maka pencipta atau ahli warisnya berhak menuntut pemegang hak cipta supaya nama penciptanya tetap dicantumkan dalam ciptaannya.

Menciptakan sebuah karya potret tidak lepas dari adanya pihak yang di potret dan pihak yang memotret, hak privasi pada potret dimiliki oleh seseorang sebagai model potret tersebut, yang berhak dapat mempublikasikan atau tidak secara umum atau menggunakannya untuk kepentingan komersial. Sehingga fotografer atau pun orang yang mengambil potret harus mendapatkan izin maupun membuat perjanjian terlebih dahulu. Karna tidak setiap orang yang dipotret akan setuju bahwa potretnya dipublikasikan. Sudah seharusnya jika ingin menggunakan atau menggandakan suatu potret seseorang harus mendapatkan izin tertulis atau lisensi dari pemegang hak cipta dari orang yang dipotret. Pada Pasal 80 ayat (1) Undang-Undang Nomor 28 tahun 2014 Tentang Hak Cipta menyatakan: "Kecuali diperjanjikan lain, pemegang Hak Cipta atau pemilik Hak Terkait berhak memberikan Lisensi kepada pihak lain berdasarkan perjanjian tertulis untuk melaksanakan perbuatan sebagaimana dimaksud dalam Pasal 9 ayat (1), Pasal 23 ayat (2), Pasal 24 ayat (2), dan Pasal 25 ayat (2)".

Perlindungan terhadap subjek dalam potret semakin jelas terlihat apabila subjek dalam potret yang menyewa atau membayar jasa fotografer untuk melakukan pemotretan terhadap dirinya. Sebagaimana diatur dalam Pasal 36 undang - undang no.28 tahun 2014 tentang Hak Cipta menjelaskan bahwa "Kecuali diperjanjikan lain, Pencipta dan Pemegang Hak Cipta atas Ciptaan yang dibuat dalam hubungan kerja atau berdasarkan pesanan yaitu pihak yang membuat Ciptaan" Berdasarkan ketentuan ini fotografer memang mendapatkan keistimewaannya menjadi pemegang hak cipta atas ciptaan, namun apabila dalam perjanjian jual beli jasa, subjek dalam potret tidak mengizinkan fotografer untuk melakukan publikasi dalam akun media sosial untuk kepentingan komersil, maka fotografer tidak dapat menggunakan hak ekonomi terhadap potret tersebut. Hal tersebut dikarenakan ketika seorang yang menjadi subjek membayar kepada fotografer, kemudian potret yang dihasilkan merupakan hasil dari perpaduan antara kinerja subjek dalam potret dan fotografer, subjek dalam fotografer memiliki hak atas pencipta atau pemegang hak cipta sebagaimana penjelasan Fredyanto Hascaryo dalam suatu forum diskusi online (Hascaryo, 2008) Berdasarkan uraian diatas, subjek dalam potret mempunyai perlindungan hak cipta karena subjek dalam potret memiliki andil atas terciptanya hasil karya potret yang bernilai seni, hal tersebut untuk menghindari penggunaan potret atas dirinya yang digunakan oleh fotografer atau pihak lain untuk ingin mendapatkan keuntungan komersil dari potret tersebut yang kemudian merugikan dirinya.

\subsection{Akibat Hukum Bagi Subjek Yang Menggunakan Potret Artis Sebagai Cover Novel Fanfiksi Secara Komersial Tanpa Hak Berdasarkan Undang-Undang Nomor 28 Tahun 2014 Tentang Hak Cipta}


Hak Kekayaan Intelektual adalah terjemahan resmi dari Intellectual Property Rights. Berdasarkan subtansinya, Hak Kekayaan Intelektual berhubungan dengan benda tidak berwujud dan dapat dijadikan sebagai objek jaminan fidusia, walaupun penentuan nilai atau nominal dari hak cipta belum ada ketentuan yang baku akan tetapi para pihak dapat meminta pertimbangan dari para ahli (Tjoanda, 2020: 47).

Hak Cipta muncul sebagai bagian yang tidak terpisahkan Hak Kekayaan Intelektual yang bergerak di bidang seni, sastra, dan ilmu pengetahuan dimunculkan untuk memotivasi dan mendorong kreativitas pencipta yang hal ini dapat menciptakan pertumbuhan ekonomi yang berbasis pada ruang lingkup seni, sastra dan ilmu pengetahuan. Hak Cipta adalah hak eksklusif pencipta yang timbul secara otomatis berdasarkan prinsip deklaratif setelah suatu ciptaan diwujudkan dalam bentuk nyata tanpa mengurangi pembatasan sesuai dengan ketentuan peraturan perundang-undangan. Hal itu sudah tertulis dalam undang-undang no 28 tahun 2014 tentang hak cipta pada Pasal 1 angka 1. Keberadaan hak eksklusif melekat erat kepada pemiliknya atau pemegangnya yang merupakan kekuasaan pribadi atas ciptaan, Oleh karena itu tidak ada pihak lain yang boleh memanfaatkan hak cipta kecuali atas izin pemegangnya.

Hak cipta mengandung hak ekonomi (economic right) dan hak moral (moral right) dari pemegang hak cipta itu sendiri. Hak ekonomi adalah hak untuk memperoleh keuntungan ekonomi atas hak cipta. Hak ekonomi ini berupa keuntungan sejumlah uang yang diperoleh karena penggunaan hak ciptanya tersebut oleh dirinya sendiri, atau karena digunakan oleh pihak lain berdasarkan izin yang diberikan. Bila melakukan perbuatan melawan hukum, atau tidak memenuhi suatu perjanjian (wanprestasi) yang telah disepakati baik dengan lembaga Manajemen Kolektif ataupun tidak dianggap sebagai perbuatan pelanggaran hak cipta, dan apabila bila terbukti telah memenuhi salah satu kriteria dari pelanggaran hak cipta, maka setiap pelanggar harus mendapatkan hukuman yang setimpal dengan perbuatan yang telah dilakukannya. Perlindungan hak cipta melalui undang-undang hak cipta tentunya akan memberikan perlindungan hukum bagi para pencipta. Maka hak cipta ialah hak yang melekat pada setiap individu sebagai bentuk penghargaan atas hasil karya intelektual seseorang dalam bentuk nyata, karena tidak semua orang dapat membuat suatu karya atas olah pikirnya sendiri. Sehingga segala bentuk ciptaan yang menjadi produk dari hasil pemikiran seseorang memiliki hak yang melekat padanya. Hak cipta merupakan hak kebendaan yang tidak berwujud yang dapat dikuasai oleh hak milik yang dapat dirasakan manfaatnya.

Dilarang oleh undang-undang artinya undang-undang hak cipta tidak memperkenankan atau melarang keras perbuatan itu dilakukan oleh orang yang tidak berhak, karena tiga hal, yakni (Lopes, 2013: 48):

1) Merugikan pencipta atau pemegang hak cipta, seperti memfotokopi sebagian atau seluruhnya hasil ciptaan orang lain kemudian perjual belikan kepada masyarakat luas;

2) Merugikan kepentingan negara, misalnya mengumumkan suatu ciptaan yang bertentangan dengan kebijakan pemerintah di bidang pertahanan dan keamanan;

3) Bertentangan dengan ketertiban umum dan kesusilaan, misalnya memperbanyak dan menjual video compact disc (vcd) porno yang dapat merusak mental bangsa.

Setiap pencipta atau pemegang hak cipta memiliki kebebasan untuk dapat menggunakan hak ciptanya, akan tetapi undang-undang menentukan pula adanya pembatasan terhadap penggunaan hak cipta itu. Pembatasan tersebut dimaksudkan agar para pencipta dalam kegiatan kreatif dan inovatifnya tidak melanggar norma-norma atau 
asas-asas kepatutan yang berlaku dalam kehidupan bermasyarakat dan bernegara, terutama di negara hukum seperti Indonesia mengingat hasil ciptaan umumnya akan dijual ke pasar baik dalam dan luar negeri untuk memperoleh keuntungan ekonomis bagi para pencipta atau pemegang izin guna dapat dinikmati oleh masyarakat luas. Hal tersebut telah ditentukan pembatasannya oleh undang-undang, maka kebebasan penggunaan hak cipta tidak boleh melanggar pembatasan tersebut. Adapun pembatasan penggunaan hak cipta yang tidak boleh dilanggar dapat dibagi dalam 3 (tiga) ha1, yakni (Muhammad, 2007: 116):

a) Pertama yaitu kesusilaan dan ketertiban umum. Keterbatasan penggunaan hak cipta tidak boleh melanggar pada kesusilaan dan ketertiban umum. Contoh hak cipta yang melanggar kesusilaan adalah penggunaan hak untuk mengumumkan atau memperbanyak kalender bergambar wanita atau pria tanpa busana atau telanjang dan kebebasan seks atau pornografi, sedangkan yang termasuk melanggar ketertiban umum adalah memperbanyak dan menyebarkan buku yang berisi ajaran yang membolehkan wanita bersuami lebih dari satu orang atau disebut juga dengan poliandri.

b) Kedua yaitu fungsi sosial hak cipta. Kebebasan penggunaan hak cipta tidak boleh meniadakan atau mengurangi fungsi sosial daripada hak cipta tersebut. Fungsi sosial hak cipta adalah memberi kesempatan kepada masyarakat luas untuk memanfaatkan ciptaan seseorang guna kepentingan pendidikan dan ilrnu pengetahuan, bahan pemecahan masalah, pembelaan perkara di pengadilan atau bahkan bahan untuk ceramah, akan tetapi harus disebutkan sumbernya secara lengkap.

c) Ketiga yaitu pemberian lisensi wajib. Kebebasan penggunaan hak cipta tidak boleh meniadakan kewenangan dari negara untuk mewajibkan para pencipta atau pemegang hak cipta memberikan lisensi (compulsory licensing) kepada pihak lain untuk mau menerjemahkan atau memperbanyak hasil ciptaannya dengan imbalan yang wajar. Pemberian lisensi wajib didasarkan pada pertimbangan tertentu, yakni bila negara memandang perlu atau menilai suatu ciptaan sangat penting artinya bagi kehidupan masyarakat dan negara, misalnya untuk kepentingan ilmu pengetahuan, pendidikan atau pengajaran, penelitian, pertahanan atau keamanan, dan ketertiban yang sangat membutuhkan pemakaian atas ciptaan tersebut.

Sebagaimana telah tertulis dalam Pasal 1 angka 24 Undang-Undang Hak Cipta, Penjualan Novel Fanfiksi di toko buku seluruh Indonesia merupakan Tindakan pelanggaran hak cipta dimana memproduksi Novel tersebut yang menggunakan potret artis sebagai cover secara komersial adalah pemanfaataan suatu ciptaan maupun produk hak terkait dengan tujuan untuk memperoleh keuntungan dari berbagai sumber atau berbayar. Walaupun disclaimer dalam Novel Fanfiksi telah dicantumkan, tetapsaja artis terkenal yang potretnya dipakai sebagai cover dalam Novel Fanfiksi tersebut mempunyai hak untuk mendapatkan royalti dari pihak yang menggunakan potretnya sebagai cover Novel Fanfiksi secara komersial dan berhak untuk menyatakan keberatan apabila setiap tindakan yang merugikan artis terkenal yang bersangkutan tersebut, sehubungan dengan karya cipta yang dikomersialkan dapat merugikan kehormatan dan reputasinya.

Pasal 20 Undang-undang no. 28 tahun 2014 tentang hak cipta menyebutkan bahwa hak terkait merupakan hak eksklusif yang terdiri dari: hak moral Pelaku Pertunjukan, hak ekonomi Pelaku Pertunjukan, hak ekonomi Produser Fonogram dan hak ekonomi Lembaga Penyiaran. Dalam pasal 21 dijelaskan pengertian Hak moral Pelaku Pertunjukan merupakan hak yang melekat pada Pelaku Pertunjukan yang tidak dapat dihilangkan atau tidak dapat dihapus dengan alasan apapun walaupun hak ekonominya telah dialihkan. 
Novel Fanfiksi termasuk kedalam sebuah distorsi ciptaan yaitu tindakan yang memutar balikkan fakta dan identitas karya pelaku pertunjukan. Novel fanfiksi mengkontruksi ulang identitas artis terkenal dan menyusun plot cerita yang berbeda dari fakta sebenarnya dan tak hanya itu Pencantuman potret artis terkenal pada cover novel fanfiksi membuat orang-orang berasumsi bahwa memang tokoh dalam novel tersebut adalah artis terkenal itu sendiri. Asumsi yang dibuat oleh orang-orang inilah yang menguntungkan pihak-pihak yang terlibat dalam penerbitan novel fanfiksi tersebut.

Hak cipta dalam sebuah karya termasuk dikategorikan dilanggar apabila seseorang yang bukan pemilik hak cipta dengan tanpa izin dari pemiliknya dan tidak mempunyai hak ataupun kewenangan apapun menggunakan, mengambil atau menyebar luaskan suatu cipta untuk kepentingan komersial atau merugikan pemilik hak cipta, tetapi apabila penggunaan dilakukan tanpa unsur komersial maka tidak dapat disebut dengan pelanggaran hak cipta, kecuali bila penggunaannya dapat mencoreng nama baik orang yang menjadi objek dalam potret. Biasanya pelanggaran hak cipta didorong oleh keinginan mencari keuntungan secara cepat mengabaikan hak moral dan hak ekonomi pencipta dan pihak yang terkait.

Sebagaimana telah di jelaskan sebelumnya, tentang ciptaan yang di lindungi oleh hak cipta, diantaranya adalah fotografi dan jenis fotografi potret memiliki perlindungan lebih khusus daripada jenis fotografi yang lainnya, hal ini berdasarkan pasal 1 angka 10 yang menyebutkan Potret adalah karya fotografi dengan objek manusia. Sehingga untuk jenis fotografi potret ini diatur tersendiri dalam Pasal 12 Undang-Undang Nomor 28 tahun 2014 tentang Hak cipta yang berbunyi sebagai berikut:

(1) Setiap Orang dilarang melakukan Penggunaan Secara komersial, Penggandaan, Pengumuman, Pendistribusian, dan/atau Komunikasi atas Potret yang dibuatnya guna kepentingan reklame atau periklanan secara komersial tanpa persetujuan tertulis dari orang yang dipotret atau ahli warisnya.

(2) Penggunaan Secara Komersial, Penggandaan, Pengumuman, Pendistribusian, dan/atau Komunikasi Potret sebagaimana dimaksud pada ayat (1) yang memuat potret 2 (dua) orang atau lebih, wajib meminta persetujuan dari orang yang ada dalam Potret atau ahli warisnya.

Penggunaan Potret dalam cover novel fanfiksi merupakan potret tokoh tokoh artis yang berbeda kemudian diedit dan dijadikan satu menjadi desain cover novel tersebut dimana dapat dikatakan sebagai modifikasi ciptaan karna cover tersebut hasil pengubahan suatu ciptaan, sebagaimana telah ditulis pada Pasal 5 ayat (1) huruf e Undang - Undang Nomor 28 Tahun 2014 Tentang Hak Cipta "Mempertahankan haknya dalam hal terjadi distorsi ciptaan, mutilasi ciptaan, modifikasi ciptaan, atau hal yang bersifat merugikan kehormatan diri atau reputasinya", yang dimaksud modifikasi ciptaan adalah mengubah atas ciptaan, dengan memodifikasi potret tanpa izin telah melanggar hak moral fotografer sebagai pencipta potret tersebut dan tokoh tokoh yang memiliki hak terkait selaku objek manusia yang berada dalam potret yang digunakan sebagai cover novel tersebut. Menurut kententuan Pasal 21 undang-Undang Nomor 28 Tahun 2014 Tentang Hak Cipta "Hak moral pelaku pertunjukan merupakan hak yang melekat pada pelaku pertunjukan yang tidak dapat dihilangkan atau tidak dapat dihapus dengan alasan apapun walaupun hak ekonominya telah diahlikan" sehingga walaupun potret tersebut dimodifikasi hak moral tersebut masi melekat dan bila digunakan tanpa izin melanggar hak moral pelaku pertunjukan sebagaimana diatur dalam Pasal 22 huruf b Undang-Undang Nomor 28 tahun 2014 Tentang Hak Cipta “ Hak moral Pelaku Pertunjukkan sebagaimana dimaksud dalam Pasal 21 meliputi hak untuk tidak dilakukannya distorsi Ciptaan, mutilasi Ciptaan, 
modifikasi Ciptaan, atau hal-hal yang bersifat merugikan kehormatan diri atau reputasinya kecuali disetujui sebaliknya"

Pelanggaran hak cipta adalah perbuatan merugikan orang lain yang mempengaruhi perkembangan dalam bidang intelektual yang menghambat upaya meningkatkan kecerdasan bangsa. Maka perlindungan terhadap hak cipta perlu untuk terus ditingkatkan. Akibat dari pelanggaran terhadap hak cipta potret terbagi menjadi dua, yaitu:

1) Dalam Hukum Perdata berupa ganti rugi

2) Dalam Hukum Pidana berupa hukuman penjara

Selain dapat di gugat secara perdata pelaku pelanggaran hak cipta terhadap Potret dapat dituntut secara pidana menurut undang-undang hak cipta diatur dalam Pasal 112 sampai 120, Adapun ketentuanan pidana nya yang terkait pelanggaran terhadap karya potret tersebut ialah dikenakan Pasal 113 ayat (3) yakni : "Setiap Orang yang dengan tanpa hak dan/atau tanpa izin Pencipta atau pemegang Hak Cipta melakukan pelanggaran hak ekonomi Pencipta sebagaimana dimaksud dalam Pasal 9 ayat (1) huruf a, huruf b, huruf e, dan/atau huruf g untuk Penggunaan Secara Komersial dipidana dengan pidana penjara paling lama 4 (empat) tahun dan/atau pidana denda paling banyak Rp1.000.000.000,00 (satu miliar rupiah)."

Akibat pelanggaran terhadap hak cipta sangat merugikan bagi pencipta dan pemegang hak cipta, karena hak cipta merupakan hak eksklusif yang terdiri atas hak moral dan hak ekonomi. Apabila hal ini dibiarkan dan tidak dilindungi, maka para pencipta dana pemegang hak cipta akan kehilangan motivasi untuk lebih kreatif membuat karya cipta yang baru, padahal hasil ciptaan dapat menunjang pertumbuhan ekonomi dan memberikan kontribusi bagi peningkatan kesejahteraan rakyat. Kesimpulan dari Penjelasan diatas adalah perbuatan pelanggaran terhadap karya potret yang digunakan secara komersial tanpa hak selain dapat digugat secara perdata orang tersebut juga dapat dituntut secara pidana ataupun dapat dilakukan kedua-duanya, namun jika ingin melakukan keduanya harus mendahulukan menyelesaikan secara perdata kemudian baru secara pidana, namun putusan perkara perdata nya tidak dapat menghapuskan hukuman pidana nya.

\subsection{Penyelesaian Sengketa Atas Potret Artis Yang Digunakan Secara Komersial Tanpa Hak Dalam Cover Novel Fanfiksi Berdasarkan Undang-Undang Nomor 28 Tahun 2014 Tentang Hak Cipta}

Undang-undang No.28 tahun 2014 Tentang Hak Cipta mengatur mengenai upaya penyelesaian apabila terjadi sengketa antara pemotret dengan orang yang dipotret. Ketentuan tersebut dimaksudkan untuk lebih memaksimalkan upaya demi mengurangi pelanggaran hak cipta dengan berusaha mewujudkan ketentuan-ketentuan hukum yang lebih efektif dan efisien. Pengaturan mengenai karya-karya Fanfiksi secara khusus dalam hukum hak cipta di negara kita memang belum ada. Akan tetapi, karya-karya yang dihasilkan oleh para penggemar ini dalam Undang-Undang Nomor 28 Tahun 2014 tentang Hak Cipta termasuk sebagai karya adaptasi. Yang dimaksud dengan adaptasi adalah mengalih wujudkan suatu Ciptaan menjadi bentuk lain. Sebagai contoh misalnya, dari buku menjadi film, dari film menjadi gambar, dari buku menjadi karya tulis lain, dan sebagainya.

Kebanyakan untuk cover Fanfiksi sendiri menggunakan potret seseorang yang digunakan sebagai tokoh tersebut yang tak lain potret artis yang diedit sedemikian rupa agar menarik sang pembaca, yang sangat rentan dengan terjadinya pelanggaran oleh orang yang tidak memiliki hak. Dengan adanya pelanggaran tersebut maka akan dipastikan timbul sengketa. Asal mula sengketa biasanya bermula pada situasi dimana ada pihak yang 
dirugikan oleh pihak lain. Biasanya ini diawali oleh perasaan tidak puas, bersifat subyektif dan tertutup.

Sebagaimana disebutkan di atas, sengketa biasanya terjadi karena pelanggaran terhadap orang lain. Jika mengarah pada pelanggaran hak eksklusif pencipta atau pemegang hak cipta, dapat dianggap sebagai pelanggaran hak cipta. Bentuk pelanggaran hak cipta berkisar pada dua aspek utama, yaitu (Sembiring, 2011: 2):

1) Dengan sengaja dan tanpa hak mengumumkan, memperbanyak atau memberi izin untuk itu. Salah satu contoh pelanggaran tersebut berupa dengan sengaja melanggar larangan untuk mengumumkan setiap ciptaan yang bertentangan dengan kebijaksanaan pemerintah di bidang pertahanan dan keamanan Negara, kesusilaan, serta ketertiban umum;

2) Dengan sengaja memamerkan, mengedarkan, atau menjual kepada umum suatu ciptaan atau barang hasil ciptaan atau barang hasil pelanggaran hak cipta.

Adapun Pelanggaran-pelanggaran lain yang dapat memicu sengketa yang telah tercantum pada Undang-undang hak Cipta sebagai berikut:

1) Sengaja dan tanpa hak pencipta atau pemegang hak cipta dan hak terkait melanggar hak ekonomi dan hak terkait

2) Menyiarkan, memamerkan mengedarkan, atau menjual kepada umum ciptaan dar hasil pelanggaran hak moral dan hak terkait

3) Memperbanyak dan menjual program computer

4) Mengumumkan ciptaan yang bertentangan dengan kebijakan pemerintah di bidang agama, pertahanan dan keamanan Negara, kesusilaan serta ketertiban umum

5) Memotret dan menyiarkan potret tanpa ijin dari pihak yang dipotret/pemegang hak cipta potret

6) Melanggar hak moral

7) Mengubah/menghilangkan informasi elektronik manajemen hak pencipta

8) Tanpa hak dari pencipta merusak, meniadakan sarana control teknologi sebagai pengaman hak cipta

9) Ciptaan menggunakan berteknologi tinggi khususnya dalam bidang cakram optik tidak meminta ijin pada pihak yang berwenang.

Pelanggaran terhadap hak cipta dapat diselesaikan secara perdata maupun secara pidana. Penyelesaian setiap sengketa hak cipta potret dan fotografi berdasarkan Pasal 95 ayat (1) Undang - Undang Nomor 28 tahun 2014 tentang Hak Cipta dapat dilakukan dengan berbagai jalur yaitu:

1) Jalur Litigasi atau Pengadilan

2) Jalur Non litigasi.atau di Luar Pengadilan.

Penyelesaian sengketa secara litigasi dan non litigasi masing-masing memiliki kelemahan dan keunggulannya sebagai berikut (Sembiring, 2011: 9-10):

1) Penyelesaian sengketa melalui litigasi dapat dikatakan sebagai penyelesaian sengketa yang memaksa salah satu pihak untuk menyelesaikan sengketa dengan perantara pengadilan, sedangkan penyelesaian sengketa melalui non litigasi dilakukan dengan berdasar pada kehendak dan itikad baik dari para pihak untuk menyelesaikan sengketa

2) Penyelesaian sengketa melalui litigasi memiliki sifat eksekutorial dalam arti pelaksanaan terhadap putusan dapat dipaksakan oleh lembaga yang berwenang. 
Sedangkan penyelesaian sengketa melalui non litigasi tidak dapat dipaksakan pelaksanaannya sebab bergantung pada kehendak dan itikad baik dari para pihak

3) Penyelesaian sengketa melalui litigasi pada umumnya dilakukan dengan menyewa jasa dari advokat/pengacara sehingga biaya yang dikeluarkan tentunya mahal

4) Penyelesaian sengketa melalui litigasi tentu harus mengikuti persyaratanpersyaratan dan prosedur-prosedur formal di pengadilan dan sebagai akibatnya jangka waktu untuk menyelesaikan suatu sengketa menjadi lebih lama. Sedangkan penyelesaian sengketa melalui nonlitigasi tidak mempunyai prosedurprosedur atau persyaratan-persyaratan formal sebab bentuk dan tata cara penyelesaian sengketa diserahkan sepenuhnya kepada para pihak.

Penyelesaian sengketa pada proses litigasi yang bersifat terbuka mengandung makna bahwa siapa saja dapat menyaksikan jalannya persidangan, terkecuali untuk acara persidangan tertentu, misalnya sengketa perkara asusila. Sedangkan sifat rahasia dari penyelesaian sengketa secara nonlitigasi berarti hanya pihak-pihak yang bersengketa yang dapat menghadiri persidangan dan bersifat tertutup untuk umum sehingga segala hal yang diungkap pada pemeriksaan, tidak dapat.

\subsubsection{Penyelesaian Sengketa Secara Litigasi}

Penyelesaian sengketa hak cipta yang dilakukan dengan jalur litigasi atau pengadilan yaitu dengan mengajukan gugatan perdata ataupun tuntutan pidana di Pengadilan Niaga pada wilayah domisili hukum pelaku pelanggaran yang diatur didalam Pasal 112 sampai 120 Undang-Undang Nomor 28 tahun 2014 Tentang Hak Cipta. Sedangkan, pihak yang dapat digugat di Pengadilan Niaga atas perkara pelanggaran terhadap karya potret yang digunakan secara komersial tanpa hak adalah seseorang baik individu atau kelompok dalam hal ini ialah penerbit dari buku novel fanfiksi yang telah menggunakan karya potret orang lain sebagai cover novel fanfiksi secara komersial tanpa hak untuk menarik minat para pembeli yang jelas merugikan hak-hak dari pencipta maupun pemilik hak cipta yaitu Fotografer maupun model yang di foto. Maka baik fotografer maupun model dapat menuntut atau pun meminta ganti rugi terhadap pelaku pelanggaran hak cipta tersebut, seperti yang sudah tertulis dalam Pasal 99 ayat (1) yaitu: "Pencipta, pemegang hak cipta, atau pemilik hak terkait berhak mengajukan gugatan ganti rugi kepada Pengadilan Niaga atas pelanggaran Hak Cipta atau produk Hak Terkait"

Selain menggugat ganti rugi fotografer maupun model dapat memohon putusan sela kepada pengadilan niaga untuk melakukan hal hal yang telah tertulis dalam pasal 99 ayat (3) huruf a dan b yaitu : "Selain gugatan sebagaimana dimaksud pada ayat (1), Pencipta, Pemegang Hak Cipta, atau Pemilik Hak Terkait dapat memohon putusan provisi atau putusan sela kepada Pengadilan Niaga

a) Meminta penyitaan Ciptaan yang dilakukan Pengumuman atau Penggandaan, dan/atau alat Penggandaan yang digunakan untuk menghasilkan Ciptaan hasil pelanggaran Hak Cipta dan produk Terkait; dan/atau

b) Menghentikan kegiatan Pengumuman, Pendistribusian, komunikasi, dan/atau Penggandaan Ciptaan yang merupakan hasil pelanggaran Hak Cipta dan Produk Hak Terkait"

Apabila terjadi pelanggaran hak cipta maka terdapat mekanisme dalam mengajukan gugatan ke Pengadilan Niaga. Mekanisme ini ditujukan untuk mengetahui tata cara dalam melakukan gugatan atas pelanggaran hak cipta. Seperti yang telah dijelaskan sebelumnya 
Seseorang yang merasa dirugikan karena ciptaannya digunakan tanpa ijinnya terlebih dahulu dapat mengajukan gugatan di Pengadilan Niaga. Pengajuan gugatan di Pengadilan Niaga harus sesuai dengan ketentuan Undang-Undang Nomor 28 Tahun 2014 tentang Hak Cipta.

Selain dapat digugat secara perdata, pelaku pelanggaran hak cipta juga dapat dituntut secara pidana. Hal ini telah diatur dalam Bab XVII Ketentuan Pidana Pasal 112 - 120 Undangundang No. 28 Tahun 2014 tentang Hak Cipta Tetapi sebelum mengajukan tuntutan pidana, harus terlebih dahulu dilakukan mediasi sebagai upaya penyelesaian sengketa hak cipta yang pertama sebagaimana tertuang dalam Pasal 95 ayat (4) Undang-Undang Nomor 28 tahun 2014 Tentang Hak Cipta, yang artinya penyelesaian sengketa dengan jalur pidana merupakan upaya terakhir (Ultimum Remidium) dalam penyelesaian sengketa hak cipta. Ketentuan ini memberikan pengecualian kepada pelanggaran hak cipta berupa pembajakan yang dapat secara langsung dituntut hukuman pidana tanpa melalui jalur mediasi terlebih dulu. Ketika perkara telah didaftarkan dan majelis hakim yang menangani perkara tersebut sudah terbentuk, maka para pihak yang bersengketa, yaitu penggugat maupun tergugat akan dipangggil oleh pengadilan untuk datang menghadap majelis hakim. Pada pertemuan antara penggugat dan tergugat dipengadilan tersebut, hakim umumnya menyarankan para pihak menempuh tahap mediasi terlebih dahulu sebelum langsung kepada proses acara pemeriksaan dipengadilan (Isnaini, 2009: 52). Pengadilan yang berwenang untuk menyelesaikan sengketa tersebut adalah Pengadilan Niaga sebagaimana disebutkan pada Pasal 95 ayat (2) dan ayat (3) Undang-undang No.28 tahun 2014 Tentang Hak Cipta, sedangkan pengadilan lainnya tidak mempunyai kewenangan untuk menangani penyelesaian sengketa hak cipta.

Selain hak ekonomi, Pasal 98 Undang-Undang Nomor 28 tahun 2014 Tentang Hak Cipta juga mengatur bahwa setiap ahli waris juga memiliki hak untuk menggugat setiap orang yang dengan sengaja dan tanpa hak, juga tanpa persetujuan melakukan pelanggaran hak moral dengan memodifikasi, mendistrosi atau memutilasi suatu ciptaan atau tidak mencantumkan nama atau sumber sehingga pelaku dapat dikategorikan memiliki iktikad buruk dengan melanggar Pasal 5 Undang-undang No.28 tahun 2014 Tentang Hak Cipta. Disamping gugatan perdata, penyelesaian sengketa juga dapat dituntut secara pidana kepada Kepolisian RI, hal ini sesuai dengan Pasal 105. Delik yang digunakan untuk hak cipta semula ialah delik aduan tetapi diubah menjadi delik biasa agar setiap penindakan pelanggaran hak cipta dapat dilajukan dengan segera tanpa perlu menunggu adanya pengaduan dari orang yang merasa dirugikan atas pelanggaran hak cipta.

Apabila penyelesaian sengketa tidak dapat dilakukan dalam jangka waktu yang terbilang cepat atau dengan proses pengambilan putusan yang terbilang lama. Maka dalam hal ini penggugat dapat mengajukan permohonan penetapan sementara, yaitu bertujuan untuk mencegah berlarut-larutnya penderitaan yang dialami oleh pencipta ataupun pihakpihak yang memiliki hak atas suatu ciptaan dan mencegah bertambahnya kerugian yang diakibatkan dari perbuatan pihak yang telah melakukan pelanggaran hak cipta. Ketentuan ini disatu sisi cukup menggembirakan karen terlihat seperti peduli pada kerugian yang dialami oleh pemegang hak cipta, tetapi dalam kasus sengketa hak cipta yang belum diketahui secara pasti pemegang hak cipta sebenarnya, ketentuan ini bisa jadi membawa kerugian bagi pihak yang dibebani kewajiban oleh penetapan sementara tersebut (Isnaini, 2009: 52).

Penetapan sementara dilakukan apabila ada permohonan secara tertulis dari pihak yang merasa dirugikan ke Pengadilan Niaga setelah memenuhi syarat-syarat yang ada di 
dalam Pasal 107 Undang-Undang Nomor 28 tahun 2014 Tentang Hak Cipta. Kemudian seperti yang telah di jelaskan pada Pasal 106 hakim akan mengeluarkan penetapan sementara sebagai berikut:

1) Mencegah masuknya barang-barang yang diduga sebagai hasil dari perbuatan pelanggaran hak cipta atau hak terkait ke dalam jalur perdagangan,

2) Menarik barang dari peredaran dan melakukan penyitaan serta menyimpannya sebagai alat bukti,

3) Mengamankan dan mencegah penghilangan barang bukti oleh pelanggar,

4) Menghentikan pelanggaran agar tidak membuat kerugian yang lebih besar.

Sebagaimana diatur di dalam Pasal 108 hakim akan memutuskan untuk menolak atau mengabulkan permohonan penetapan sementara dalam jangjka waktu paling lama 2 (dua) hari sejak tanggal penunjukkan hakim yang berwenang. Upaya hukum pada umumnya dibagi menjadi dua yaitu upaya hukum biasa dan upaya hukum luar biasa. Upaya hukum biasa berupa permohonan banding ke Pengadilan Tinggi dan kasasi oleh Mahkamah Agung, sedangkan upaya hukum luar biasa yaitu berupa Peninjauan Kembali untuk kepentingan umum. Tetapi berbeda halnya dengan hak cipta, upaya hukum yang dapat ditempuh oleh pihak yang merasa kurang puas atas keputusan hakim pada persidangan sebelumnya mengenai hak cipta potret atau hak cipta lainnya sebagaimana diatur di dalam Pasal 102 Undang-undang No.28 tahun 2014 Tentang Hak Cipta hanya dapat mengajukan kasasi yang secara langsung yang dipersingkat ke Mahkamah Agung.

Permohonan kasasi diajukan paling lambat 14 (empat belas) hari sejak tanggal putusan Pengadilan Niaga diucapkan atau telah diberitahukan kepada para pihak dengan mendaftarkan kepada pengadilan yang telah memutus gugatan tersebut. Didalam sengketa hak cipta tidak mengenal upaya hukum banding karena kewenangan mengadili dimiliki oleh Pengadilan Niaga. Syarat untuk melakukan kasasi sebagaimana diatur Pasal 103 ayat (1) Undang-undang No.28 tahun 2014 Tentang Hak Cipta adalah dengan menyampaikan memori kasasi kepada panitera Pengadilan Niaga dalam waktu paling lama 14 (empat belas) hari terhitung sejak tanggal permohonan kasasi didaftarkan. Sebaliknya, dalam ketentuan Pasal 103 ayat (4) Undang-undang No.28 tahun 2014 Tentang Hak Cipta, Panitera Pengadilan Niaga wajib menyampaikan kontra memori kasasi dalam waktu paling lama 7 (tujuh) hari terhitung sejak Panitera menerima memori kasasi. Mahkamah Agung harus memberikan putusan permohonan kasasi paling lama 90 (Sembilan puluh)hari sejak diterimanya permohonan kasasi oleh Mahkamah Agung sebagaimana dinyatakan dalam Pasal 104 ayat (2) Undang-Undang Nomor 28 tahun 2014 Tentang Hak Cipta.

\subsubsection{Penyelesaian Sengketa Secara Non Litigasi}

Penyelesaian sengketa hak cipta selanjutanya yaitu melalui jalur non litigasi atau diluar pengadilan yaitu melalui Arbitrase dan Alternatif Penyelesaian Sengketa, dalam permasalan atau sengketa bisnis, umumnya peneyelsaian melalui luar pengadilan, seperti arbitrase dan mediasi, lebih dipilih dibandingkan penyelesaian melalui pengadilan. Alasan yang kerap menjadi bahan pertimbangan dipilihnya kerahasiaan sengketa para pihak (Isnaini, 2009: 54).

Pengertian Arbitrase diatur di dalam Pasal 1 ayat (1) Undang-Undang Nomor 30 Tahun 1999 Tentang Arbitrase dan Alternatif Penyelesaian Sengketa, yaitu : "Alternatif Penyelesaian Sengketa adalah lembaga penyelesaian sengketa atau beda pendapat melalui prosedur yang disepakati para pihak, yakni penyelesaian di luar pengadilan dengan cara konsultasi, negosiasi, mediasi, konsiliasi, atau penilaian ahli." 
Penggunaan arbitrase dalam menyelesaikan suatu sengketa dilakukan oleh Arbiter yang terdiri dari satu orang atau beberapa orang yang ditunjuk oleh Pengadilan atau oleh Lembaga Arbitrase maupun dengan dipilih secara langsung oleh para pihak yang guna memberikan keputusan mengenai sengketa yang diserahkan penyelesaiannya melalui arbitrase. Hasil dari Arbitrase yaitu berupa sebuah putusan. Bila para pihak telah memilih penyelesaian melalui arbitrase dan terikat perjanjian didalamnya, maka pengadilan harus menyatakan dirinya tidak berwenang untuk mengadili sengketa jika suatu saat timbul permasalahan hukum diantara para pihak. Hal ini seperti diatur dalam Pasal 3 UndangUndang Arbitrase dan Alternatif Penyelesaian Sengketa yang menyatakan bahwa pengadilan negeri tidak berwenang untuk mengadili sengketa para pihak yang telah terikat dalam perjanjian arbitrase (Isnaini, 2009: 55).

Pada umumnya lembaga arbitrase mempunyai kelebihan dibandingkan dengan lembaga peradilan. Kelebihan tersebut anatara lain:

1) Kerahasiaan sengketa para pihak dijamin;

2) Dapat dihindari kelambatan yang diakibatkan karena prosedural dan administrative dalam proses peradilan di pengadilan;

3) Para pihak dapat memilih arbiter secara langsung sesuai dengan kesepakatan yang menurut keyakinannya mempunyai pengetahuan, pengalaman serta latar belakang yang cukup mengenai masalah yang disengketakan, jujur dan adil;

4) Para pihak yang berpekara dapat menentukan pilihan hukum yang dapat ditempuh untuk menyelesaikan masalahnya serta proses dan tempat penyelenggaraan arbitrase; dan

5) Putusan arbiter merupakan putusan yang mengikat para pihak dan dengan melalui tata cara atau prosedur sederhana ataupun langsung dapat dilaksanakan.

Namun demikian, apa yang menjadi keutamaan arbitrase diatas kadang tidak sesuai dengan kenyataan, sebab di negara-negara tertentu proses peradilan dapat lebih cepat dari proses arbitrase. Akhirnya, dalam hal ini satu-satunya kelebihan arbitrase dibandingkan dengan pengadilan umum hanyalah sifat kerahasiaannya, karena keputusan yang dihasilkan tidak dipublikasikan (Isnaini, 2009).

Alternatif penyelesaian sengketa atau sering disebut sebagai Atrenative Dispute Resolution (ADR) merupakan ekspresi responsive atas ketidak puasan (dissatisfaction) penyelesaian sengketa melalui proses litigasi atau pengadilan yang konfrontatif dan zwaarwichtig (njelimet-bertele-tele) (Mu'adi, 2010: 66). Pengertian dari Alternatif Penyelesaian Sengketa menurut Pasal 1 ayat (10) Undang-Undang Nomor 30 Tahun 1999 tentang Artbitrase dan Alternatif Penyelesaian Sengketa adalah suatu lembaga penyelesaian sengketa atau beda pendapat dengan melalui berbagai prosedur yang telah disepakati bersama-sama oleh para pihak yang berperkara, yakni melakukan penyelesaian diluar pengadilan dengan beberapa cara, yaitu (Yuniarti, 2017):

1) Negosiasi merupakan sebuah cara untuk mencari penyelesaian masalah melalui diskusi atau musyawarah secara langsung antara para pihak yang berperkara yang kemudian hasilnya harus diterima oleh masing-masing pihak.

2) Mediasi merupakan suatu upaya penyelesaian sengketa dengan melibatkan pihak ketiga yang netral dan tidak memiliki kewenangan untuk mengambil keputusan, yang kemudian dapat membantu para pihak yang bersengketa mencapai penyelesaian (solusi) yang bisa diterima oleh masing-masing pihak

3) Konsiliasi adalah penyelesaian sengketa dengan mendatangkan intervensi pihak ketiga sebagai penengah atau konsiliator, dimana konsiliator bersifat aktif, dengan 
menyusun, mengambil inisiatif dan merumuskan langkah-langkah penyelesaian sengketa, yang selanjutnya akan ditawarkan kepada para pihak yang bersengketa (Yuniarti, 2017).

4) Konsultasi ialah suatu tindakan yang bersifat "pribadi" antara pihak tertentu yang merupakan klien dengan pihak lain yang merupakan pihak konsultan, dimana pihak konsultan akan memberikan pendapatnya terhadap suatu masalah kepada klien sesuai dengan keperluan dan kebutuhan kliennya.

5) Penilaian para ahli merupakan pandangan atau pendapat para ahli terhadap suatu hal yang bersifat teknis sesuai dengan bidang keahliannya.

Terbatasnya penyelesaian di luar pengadilan tersebut tentunya juga membatasi proses penyelesaian di luar pengadilan sebagai salah satu penyelesaian sengketa yang saat ini lebih gencar dilakukan. Semestinya penyelesaian di luar pengadilan juga digencarkan dan diupayakan dengan sungguh-sungguh, supaya permasalahan bisa diselesaikan dengan kekeluargaan (Muchtar A H Labetubun, 2019: 161). Pemilihan orang yang berkewajiban menyelesaikan sengketa tertentu sebagai pihak ketiga atau penengah dalam penyelesaian ini sama dengan pemilihan seorang Arbiter yaitu dengan dipilih sendiri oleh para pihak ataupun ditunjuk oleh pengadilan.

Pada awalnya, penyelesaian sengketa melalui APS ini hanya terbatas pada penyelesaian sengketa dagang saja, namun saat ini, penyelesaian sengketa melalui APS tersebut telah bisa digunakan untuk menyelesaikan sengketa perdata, baik perdata umum maupun perdata khusus. Dan pada saat ini, sengketa dibidang HKI antara lain sengketa paten, merek, hak cipta juga telah dapat diselesaikan melalui APS tersebut. Namun, dalam realitasnya penyelesian sengketa HKI melalui APS tersebut masih saja terkendala sehingga membuat masih banyak para pihak yang bersengketa ragu untuk memilih jalur ini (Kurniawaty, 2017: 167). Maka dapat diartikan dalam hal ini fotografer sebagai pencipta atas suatu karya fotografi dan model memiliki hak atas ciptaan tersebut yang merupakan pihak yang dirugikan, dapat menggugat pelanggar tersebut baik menggunakan jalur litigasi maupun non litigasi.

\section{Kesimpulan}

Perlindungan hukum sebagai gambaran dari fungsi hukum yaitu suatu konsep dimana hukum dapat memberikan keadilan, ketertiban, kepastian, kemanfaatan dan ketentraman. Salah satu yang dilindungi oleh hukum yaitu hak cipta karya potret termasuk bagian dari Karya Fotografi dibidang seni yang merupakan suatu ciptaan yang dilindungi. Kepemilikan Hak cipta potret apabilas objeknya adalah manusia adalah orang yang di potret tersebut (Model) dan pemegang Hak cipta potret adalah pencipta yaitu fotografer. Potret memiliki hak ekslusif terdiri dari hak moral (Moral Rights) dan hak ekonomi (Economic Right) yang berlaku abadi dan tanpa batasan waktu, untuk penggunaan potret tanpa izin dari pencipta maupun pemilik hak sudah sangat jelas pelanggaran Hak cipta. Akibat hukum bagi orang yang mengubah, menggandakan maupun pendistribusian dengan tujian komersial tanpa mendapatkan izin dari pemegang hak cipta atas potret dapat digugat secara perdata dan pidana. Penyelesaian sengketa apabila pemilik potret merasa dirugikan atas pelanggaran tersebut maka dapat di selesaikan menggunakan jalur litigasi atau pengadilan dan jalur non litigasi atau di luar pengadilan yaitu alternatif penyelesaian sengketa seperti negoisasi, mediasi, dan arbitrase. 


\section{Daftar Referensi}

Arrasjid, C. (2008). Dasar-Dasar Ilmu Hukum. Sinar Grafika.

Black, R. W. (2007). Fanfiction Writing and the Construction of Space. E-Learning and Digital Media, 4(4), 384-397. https:// doi.org/10.2304/elea.2007.4.4.384

Darmawan, A. (2018). Penggunaan Potret Sebagai Sarana Promosi Ditinjau Dari Undang-Undang Hak Cipta. Universitas Bandar Lampung.

Fuady, M. (2011). Pengantar Hukum Bisnis : Menata Bisnis Modern di Era Global. Citra Aditya Bakti.

Hariyani, I., Serfiyani, C. Y., \& Serfianto, R. (2018). Buku Pintar Haki Dan Warisan Budaya. Gadjah Mada University Press.

Hascaryo, F. (2008). Foto Sebagai Hak Kekayaan Intelektual. Fotografer.Net. https:// www.fotografer.net/ forum/view.php?id=3193750701

Isnaini, Y. (2009). Hak Cipta Dan Tantangannya Di Era Cyber Space. Ghalia Indonesia.

Kurniawaty, Y. (2017). Efektivitas Alternatif Penyelesaian Sengketa Dalam Sengketa Kekayaan Inteletual (Alternative Dispute Resolution On Intellectual Property Dispute). Jurnal Legislasi Indonesia, 14(2), 163-170. jurnal.peraturan.go.id/index.php/jli/article/view/98

Labetubun, Muchtar A H. (2019). Penyelesaian Sengketa Hak Atas Logo (Suatu Kajian Overlapping Hak Cipta dan Merek). ADHAPER: Jurnal Hukum Acara Perdata, 5(1), 151 166. https://doi.org/10.36913/jhaper.v5i1.93

Labetubun, Muchtar A H, \& Fataruba, S. (2016). Peralihan Hak Cipta Kepada Ahli Waris Menurut Hukum Perdata. SASI, 22(2), 1-11. https:// fhukum.unpatti.ac.id/jurnal/sasi/article/view/163

Labetubun, Muchtar Anshary Hamid. (2018). Aspek Hukum Hak Cipta Terhadap Buku Elektronik (E-Book) Sebagai Karya Kekayaan Intelektual. SASI, 24(2), 138-149. https:// doi.org/10.47268/sasi.v24i2.128

Labetubun, Muchtar Anshary Hamid. (2021). A Legal Awareness of Copyright on Regional Song Creators. International Journal of Law Reconstruction, 5(1), 49-61. https:// doi.org/10.26532/ijlr.v5i1.15406

Lipton, J. D. (2014). Copyright and The Commercialization of Fanfiction. Houston Law Review, 52(2), 425-466. https://houstonlawreview.org/article/3989-copyright-and-thecommercialization-of-fanfiction

Lopes, F. M. (2013). Penegakan Hukum Terhadap Pelanggaran Hak Cipta Di Bidang Musik Dan Lagu. Lex Privatum, 1(2), 44-57. https:// ejournal.unsrat.ac.id/index.php/lexprivatum/article/view/1703

Lutviansori, A. (2010). Hak Cipta dan Perlindungan Folklor di Iindonesia. Graha Ilmu.

Marzuki, P. M. (2016). Penelitian Hukum,. Kencana. https:/ / doi.org/340.072

Mu'adi, S. (2010). Penyelesaian Sengketa Hak Atas Tanah Perkebunan Dengan Cara Litigasi Dan Nonlitigasi. Pressti Pustaka.

Muhammad, A. (2007). Kajian Hukum Ekonomi Hak Kekayaan Intelektual. Citra Aditya Bakti. 
Rahayu, S. W. (2000). Perlindungan Terhadap Hak Ekonomi Pencipta Musik Dan Lagu Di Indonesia Berdasarkan UU no 12 Tahun 1997 Dikaitkan Dengan Perjanjian TRIPs-WTO. Universitas Padjajaran.

Sembiring, J. J. (2011). Cara Menyelesaikan Sengketa Diluar Pengadilan (Negosiasi, Mediasi, Konsiliasi, \& Arbitrase). Visi Media.

Seputaran Pengetahuan. (2020). Seni: Pengertian, Fungsi, Jenis, Cabang dan Sifat Dasarnya. Seputarpengetahuan.Co.Id.

https://www.seputarpengetahuan.co.id/2020/04/seni.html

Sutedi, A. (2009). Hak Atas Kekayaan Intelektual. Sinar Grafika.

Tjoanda, M. (2020). Karakteristik Hak Cipta Sebagai Objek Jaminan Fidusia. Batulis Civil Law Review, 1(1), 47-53. https:/ / doi.org/10.47268/ballrev.v1i1.424

Usman, R. (2006). Hukum Hak Atas Kekayaan Intelektual : Perlindungan dan Dimensi Hukumnya di Indonesia. Alumni.

Utomo, T. S. (2010). Hak Kekayaan Intelektual di Era Global : Sebuah Kajian Kontemporer. Graha Ilmu.

Yuniarti, S. (2017). Ragam dan Bentuk Alternatif Penyelesaian Sengketa. Business Law. https:// business-law.binus.ac.id/2017/05/31/ragam-dan-bentuk-alternatifpenyelesaian-sengketa/ 